\title{
The Impact of Harmful Algal Blooms on USACE Operations
}

\author{
by I. Linkov, F. K. Satterstrom, D. Loney, and J. A. Steevens
}

PURPOSE: Algal blooms have recently attracted significant attention due to their human and ecological effects. The aim of this technical note is to assess the importance of freshwater harmful algal blooms (HABs) to U.S. Army Corps of Engineers (USACE) operations through a literature review and surveys from regional Corps personnel who manage algal blooms and related issues. This note discusses algal bloom formation factors, occurrence, impact, and management for both the literature review and USACE surveyed staff.

ALGAL BLOOM BACKGROUND INFORMATION: Under favorable conditions, algae multiply rapidly and accumulate in large numbers, creating an event referred to as an algal bloom. Algal blooms have occurred throughout recorded history around the world (Paerl 2008). Freshwater algal blooms commonly consist of many cyanobacterial algal strains, also called "blue-green" algae for their color (Woods Hole Oceanographic Institute 2008; Vézie et al. 1998, 2002).

Algal blooms can prove harmful through reductions in dissolved oxygen (DO) and toxin release. Low DO occurs primarily through algal decay, competing for DO with other ecological uses such as respiration (Robarts et al. 2005; Connolly et al. 2004). When DO levels drop too low, a common result can be fish kills (Mhlanga et al. 2006). Toxin release arises when algae species produce toxins such as microcystin, saxitoxin, brevetoxin, ciguatoxin, or domoic acid (Van Dolah 2000). There is still much to be understood concerning the role toxins play as a function aspect of algal blooms, but toxins may be a predatory response giving the algae a competitive edge (Huisman et al. 2005). Microcystis, a hepatotoxin created by the Microcystis algae, is most frequently cited in reports of cyanobacteria-related poisoning in humans and livestock (Chorus and Bartram 1999) and is the dominant cyanobacteria in North America (Carmichael 2005). It is important to realize that not all algal blooms are harmful and that this note only addresses HABs.

HABs are an important research and management priority for more than nine federal agencies due to complex patterns of formation and largely unexplained mechanisms of progression. The economic and environmental impacts of HABs have been estimated to exceed \$1 billion over the past decade (National Oceanic and Atmospheric Administration (NOAA) 2008). Due to these impacts, Congress enacted the Harmful Algal Bloom and Hypoxia Research and Control Act of 1998 (HABHRCA; reauthorized in 2004), which mandated that Federal agencies complete a scientific assessment and plan for successful management of HABs.

USACE deals with HABs in many of its projects and actively maintains the Aquatic Nuisance Species Research Program (ANSRP). A recent study (Cole et al. 2005) examined the impacts of freshwater aquatic nuisance species on USACE-operated civil works projects. The study found that while aquatic vascular plants are the largest nuisance at locks, dams, and waterways, algae were reported as a nuisance species at five projects, or 4 percent of those sampled. The authors of the 
report suggest that the problems that algae cause at Corps projects warrant further study due to the difficulty in quantifying the algae's impact.

METHODS UTILIZED DURING THE STUDY: To assess the importance of algal blooms in USACE operations, a limited literature review was conducted and regional Corps personnel across the United States were surveyed.

The literature review used the Science Citation Index (SCI) Expanded Database, the Google search engine for gray literature, federal and state reports, and references cited in review and original papers. Search terms included HABs, algal bloom, cyanobacteria, microcystin, and microcystis. Of the several hundred candidate papers returned from the searches, approximately 60 papers were reviewed. Based on this sample, additional targeted research was conducted to resolve any gaps in the initial search.

Staff interviewed six USACE personnel from five different divisions, selected based on geographical distribution and direct involvement in projects related to USACE operations and maintenance. The interviews followed a structured protocol, including questions about the individual's position and responsibilities within the Corps, the extent and evolution of HABs in his/her district, management actions taken in response to blooms, available monitoring data, and opinions on what information would be useful for better management response to blooms. Interviews focused on blue-green algae and freshwater blooms. Staff recorded each interview and sent written summaries to interviewees for accuracy review.

ALGAL BLOOM LITERATURE REVIEW: The literature review focused on environmental factors that lead to algal bloom development and management actions that can be taken to prevent bloom formation. Figure 1 displays many of these factors - isolation/irradiance, nutrients, temperature, turbulence, and flushing - and how they interact in a reservoir.

Environmental conditions leading to harmful algal blooms. Environmental factors thought to control HAB formation and proliferation are outlined in Table 1 and Figure 1. Algal bloom factors can be summarized into two primary categories: physical and chemical.

Physical properties of reservoirs may lead to increased algal bloom activity. Major factors residence time, stratification, shading, and temperature (Paerl 1996) - are discussed in detail below.

- Residence time can affect the accumulation and turnover rates of algae and nutrients. Algal accumulation occurs when the growth rate is greater than the flushing rate. When the flushing rate is high, algae cannot accumulate before being swept downstream (Sthapit et al. 2008; Verspagen et al. 2006). Flushing's potency can be further increased with mixing techniques to ensure algae removal (Nakano et al. 2001). Additionally, shortened residence times flush nutrients from a water body quickly, in turn influencing the nutrient load of the system (Wissel et al. 2005). 


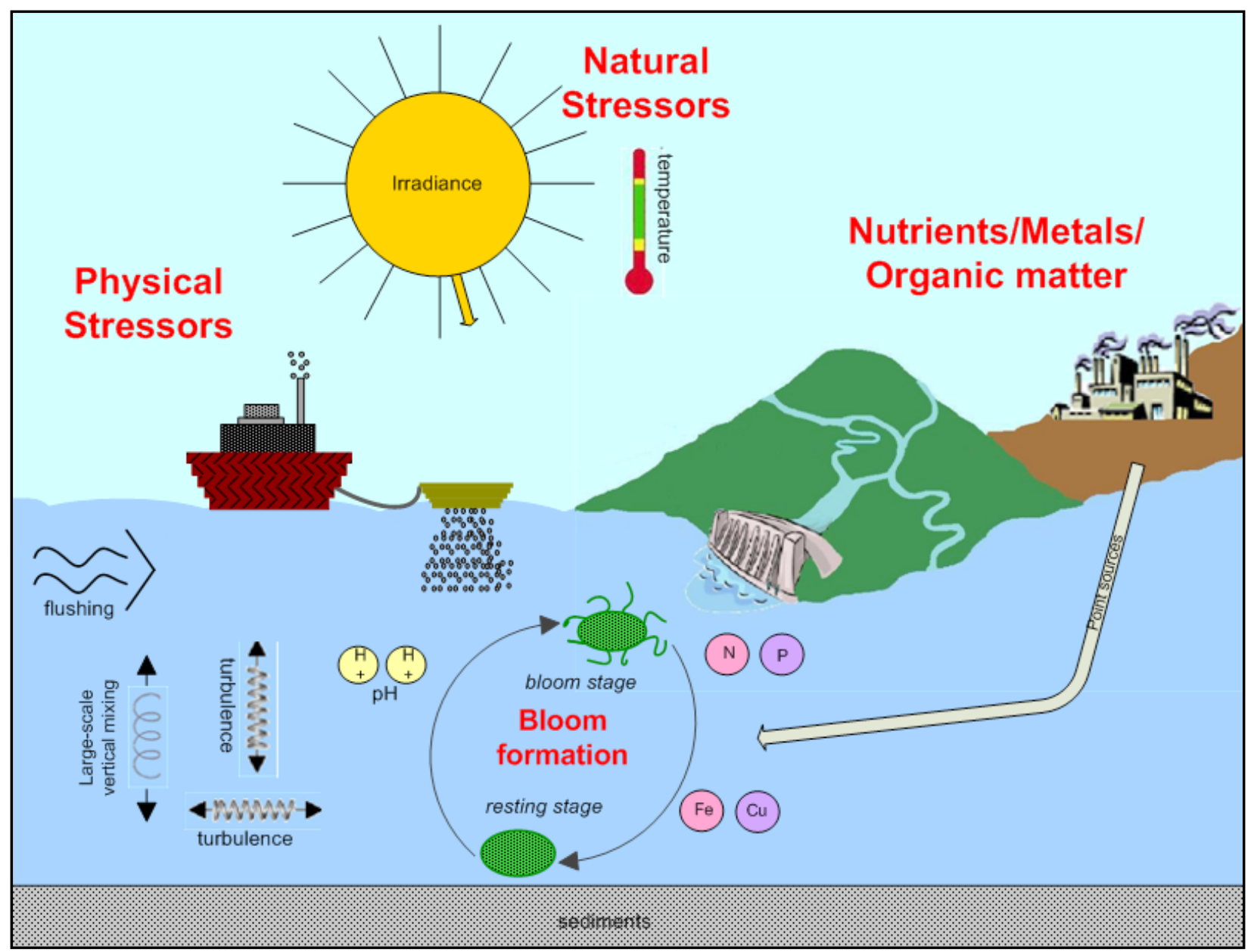

Figure 1. Algal bloom environmental factors (Linkov et al. 2007).

- Stratification promotes algal growth by creating a vertical temperature gradient within a reservoir. Algae take advantage of the gradient by adjusting their buoyancy to move in the water column, utilizing resources throughout the water column to maintain optimal growth (Rolland et al. 2005; Kunz and Diehl 2003; Ji and Franks 2007).

- Shading, and the greater issue of insolation, determines the amount of energy striking the water surface. Light tends to directly influence growth rate; the greater the intensity of light striking the surface, the higher growth rate algae will experience. Algal growth rates can be reduced by reducing the amount of energy striking the water surface (Repka et al. 2004).

- Certain algal species reproduce optimally within a certain range of temperatures. Any deviation from that range causes the species to reduce its reproduction rate (Zhaosheng et al. 2007).

Four major chemical factors that influence HAB development are $\mathrm{pH}$, nitrogen and phosphorous inputs, salinity, and trace metal inputs (Paerl 1996). For the majority of freshwater blooms, the effect of $\mathrm{pH}$, salinity, and trace metal changes on growth are minimal. Nitrogen and phosphorous loading dominate chemical algal growth. 


\section{Table 1. Management actions that can influence algal blooms (factors and effects from Paerl (1996)).}

\begin{tabular}{|c|c|c|}
\hline Factors & Effects and Impacts & Potential for USACE Management \\
\hline \multicolumn{3}{|c|}{ Physical } \\
\hline $\begin{array}{l}\text { Flushing/altered } \\
\text { water residence } \\
\text { time }\end{array}$ & $\begin{array}{l}\text { Potential removal mechanism for } \\
\text { blooms, if flushing exceeds growth } \\
\text { rates of bloom taxa }\end{array}$ & $\begin{array}{l}\text { Yes. In some instances, USACE has ability } \\
\text { to alter water flow from a dam, but other } \\
\text { factors (such as water allocation, operating } \\
\text { rules, or needs of endangered fish species) } \\
\text { may take precedence }\end{array}$ \\
\hline $\begin{array}{l}\text { Large-scale } \\
\text { vertical mixing }\end{array}$ & $\begin{array}{l}\text { Counteracts near-surface } \\
\text { accumulations of buoyant bloom } \\
\text { populations. Forces competition for } \\
\text { light and nutrients with more } \\
\text { desirable, non-buoyant eukaryotic } \\
\text { taxa }\end{array}$ & $\begin{array}{l}\text { Yes, although large-scale mixing may be } \\
\text { damaging to other ecosystem components }\end{array}$ \\
\hline $\begin{array}{l}\text { Small-scale } \\
\text { turbulence (shear) }\end{array}$ & $\begin{array}{l}\text { May disrupt blue-green algal } \\
\text { filaments, colonies, aggregates and } \\
\text { mutualistic associations with other } \\
\text { microflora and microfauna }\end{array}$ & Unknown \\
\hline $\begin{array}{l}\text { Shading (reduced } \\
\text { surface } \\
\text { irradiance) }\end{array}$ & $\begin{array}{l}\text { Can alter phytoplankton community } \\
\text { composition and can negatively affect } \\
\text { blue-green algal surface bloom taxa }\end{array}$ & $\begin{array}{l}\text { Would only work on small bodies of water. } \\
\text { Used in Australia for water supply reservoirs }\end{array}$ \\
\hline Temperature & $\begin{array}{l}\text { Generally, temperatures in excess of } \\
20^{\circ} \mathrm{C} \text { accompanied by stratification } \\
\text { and high nutrient loading can promote } \\
\text { blooms }\end{array}$ & $\begin{array}{l}\text { USACE, in some instances, has ability to } \\
\text { release water from selected depths behind a } \\
\text { dam; the temperature and dissolved oxygen } \\
\text { content of this water can be depth- } \\
\text { dependent }\end{array}$ \\
\hline \multicolumn{3}{|c|}{ Chemical } \\
\hline $\begin{array}{l}\text { Nutrient }(\mathrm{N} \text { and } \mathrm{P}) \\
\text { inputs }\end{array}$ & $\begin{array}{l}\text { Long-term (months, years) reductions } \\
\text { in both } \mathrm{N} \text { and } \mathrm{P} \text { inputs are frequently } \\
\text { effective in reducing blue-green algal } \\
\text { bloom potentials; low } \mathrm{N}: \mathrm{P} \text { loading } \\
\text { ratios }(<20) \text { often caused by } \\
\text { excessive } \mathrm{P} \text { loading can enhance } \\
\text { bloom potential }\end{array}$ & $\begin{array}{l}\text { Watershed management practices can be } \\
\text { used to mitigate nutrient levels in water } \\
\text { flowing into reservoirs; selective withdrawal } \\
\text { and management of reservoir stratification } \\
\text { can remove nutrients and alter redox } \\
\text { potential at the sediment/water interface to } \\
\text { reduce release into the water }\end{array}$ \\
\hline $\mathrm{pH}$ modifications & $\begin{array}{l}\text { Can alter phytoplankton community } \\
\text { composition; low } \mathrm{pH}(<6.0) \text { favors } \\
\text { eukaryotes, and high } \mathrm{pH}(>8.0) \text { favors } \\
\text { cyanobacteria }\end{array}$ & $\begin{array}{l}\text { Can be altered indirectly by flushing, } \\
\text { selective withdrawal, and changes in the } \\
\text { submerged aquatic macrophyte community }\end{array}$ \\
\hline Salinity & $\begin{array}{l}\text { Salinity in excess of a few } \%_{\circ} \text { (as } \\
\mathrm{NaCl} \text { can be an effective barrier to } \\
\text { development and persistence of } \\
\text { many nuisance species }\end{array}$ & $\begin{array}{l}\text { Inappropriate for water used for drinking } \\
\text { water supply }\end{array}$ \\
\hline Trace metals & $\begin{array}{l}\text { Under high } \mathrm{N} \text { and } \mathrm{P} \text { loading } \\
\text { conditions, restricted availability of Fe } \\
\text { may control phytoplankton growth; } \\
\text { cyanobacteria are able to compete } \\
\text { effectively for low levels of Fe; no } \\
\text { convincing evidence for other trace } \\
\text { metal limitations }\end{array}$ & $\begin{array}{l}\text { Copper toxicity or manganese deficiency for } \\
\text { control }\end{array}$ \\
\hline
\end{tabular}


Nitrogen and phosphorous concentrations influence species selection and growth. Species become favored as the N:P ratio shifts. Ratios less than 15 tend to favor cyanobacteria while ratios greater than 20 tend to favor eukaryotic species (Paerl 2008). Besides the N:P ratio, nutrient concentrations affect the general rate of growth. Regions with high nutrient concentrations will experience a greater biomass increase than nutrient-poor regions.

The effect of nitrogen and phosphorous loading is shown in the experimental record. An Argentinian study positively associates phosphorous with HABs (Amé et al. 2003) and a Washington study places algal biomass peaks with high nitrogen concentrations (Nelson et al. 2003). A study in the Baltic Sea has also positively associated algae levels with total nitrogen (Pertola et al. 2005). At the same time, high nitrogen and phosphorous levels do not predict algal growth. Various investigations in Texas have found that algae occurrence is inversely related to surface water-soluble reactive phosphate and ammonium concentrations at a statistically insignificant level (Rhudy et al. 1999).

Algal bloom management techniques. Table 1 identifies USACE management actions that may influence HAB formation and proliferation.

In general, USACE can have a greater influence on the physical factors controlling HABs than on the chemical factors. Many actions are directly related to water management. In some instances, USACE may be able to alter water flow to decrease residence time, increase shear forces, and enhance mixing within a reservoir (Verspagen et al. 2006; Nakano et al. 2001). USACE can also affect vertical mixing and stratification in the water column by controlling water intake or artificial mixing (Becker et al. 2006). Although mixing the water in a reservoir may not be a practical option for many managers, controlled downstream releases of algae may be; such releases can prevent the congregation of algae and dilute toxin concentrations to negligible levels.

USACE operations can influence chemical factors as well through reduced nutrient loading, $\mathrm{pH}$ modifications, salinity, and trace metal shifts. Nutrient loading, generally nitrogen and phosphorous, is one of the primary forcing mechanisms in algal growth (Kim et al. 2007; McCarthy et al. 2007). Reduction to inputs can lessen the number and severity of algal bloom events (Nõges et al. 2007; Jeppesen et al. 2007). Typically, inputs result from human activities. When reservoirs do not have a clear point source contaminator, focus should shift to distributed nutrient loading from sources such as farm runoff and lawn fertilizers (Nõges et al. 2007; Glibert et al. 2006).

$\mathrm{pH}$ modifications can be made to directly control or to adjust other chemical factors that control algal growth. In certain cases, $\mathrm{pH}$ reductions can be implemented to favor species other than cyanobacteria (Shapiro 1990). pH modifications may also be implemented to reduce other chemical factors, such as phosphate release from sediments (Seitzinger 1991). While chemical additions will likely not prove cost-effective, except in small reservoirs, selective withdrawals and flushing can change $\mathrm{pH}$ regimes.

Salinity is generally not a viable control strategy as USACE must maintain salt concentrations at potable levels.

Trace metals are another algae forcing mechanism; however, trace metal limitations are rarely witnessed as direct limitations (Donnelly et al. 1997). Much more common is the control of existing blooms with the application of trace metal algaecides. Copper treatment has been used historically 
but can potentially increase the HAB growth rate and release toxins into the water column (Poovey and Netherland 2006). An additional disadvantage to copper treatment is the possibility of causing fish kills when water bodies are dosed too heavily (Watson and Yanong 2006). The ANSRP has concentrated on developing new algaecides including phytoene desaturase, acetolactate synthase, protoporphyrinogen oxidase, hydrogen peroxide, acetic acid, and natural products such as 9,10 anthraquinone (Poovey and Netherland 2006).

ALGAL BLOOMS AT RESERVOIRS MANAGED BY USACE: PERSONNEL INTERVIEW SUMMARY: In order to assess the effects of HABs on USACE operations, six USACE personnel from across the country were interviewed. The interviewees are listed in Table 2 below. Candidate personnel were selected based on geographical representation and involvement in USACE operations and maintenance projects. Because USACE does not have a formalized process for assigning HAB management responsibilities, assignment is done on an ad-hoc basis. For this reason, personnel responsible for algal blooms come from different disciplines and different organizational units within the districts.

\begin{tabular}{|c|c|c|}
\hline District & Interviewee & Position and Background \\
\hline Louisville & $\begin{array}{l}\text { Lisa Barnese-Walz } \\
\text { (Barnese-Walz 2005) }\end{array}$ & $\begin{array}{l}\text { Limnologist } \\
\text { Background includes work with algae, nutrients, lakes, and } \\
\text { streams. } \\
\text { Responsible for management of algal blooms in Indiana lakes } \\
\text { and Ohio and Kentucky bodies of water. } \\
\end{array}$ \\
\hline Norfolk & Betty Waring & $\begin{array}{l}\text { Environmental Engineer } \\
\text { Operations Branch } \\
\text { Head of the Technical Support Section, which coordinates } \\
\text { environmental permitting and assessments for maintenance } \\
\text { dredging navigation projects. }\end{array}$ \\
\hline Buffalo & $\begin{array}{l}\text { Scott Pickard (Pickard } \\
\text { 2005) }\end{array}$ & $\begin{array}{l}\text { Ecologist } \\
\text { Main area of responsibility is dredged material characterization } \\
\text { and management. }\end{array}$ \\
\hline Portland & $\begin{array}{l}\text { James Britton (Britton } \\
\text { 2005) }\end{array}$ & $\begin{array}{l}\text { Water Quality Specialist } \\
\text { Monitors water quality in the district's reservoirs and handles } \\
\text { water quality issues in planning studies and environmental } \\
\text { restoration projects. }\end{array}$ \\
\hline Jacksonville & $\begin{array}{l}\text { Mark Shafer (Shafer } \\
\text { 2005) }\end{array}$ & $\begin{array}{l}\text { Environmental Engineer } \\
\text { Water Quality section of the Planning Division. } \\
\text { Predominantly deals with Everglades restoration projects. }\end{array}$ \\
\hline Tulsa & Tony Clyde (Clyde 2005) & $\begin{array}{l}\text { Limnologist } \\
\text { Responsibilities include executing a water quality monitoring } \\
\text { program and helping with NEPA analysis and biological } \\
\text { support for aquatic ecosystem restoration projects. }\end{array}$ \\
\hline
\end{tabular}

HAB occurrence. Each interviewee's district had experienced algal blooms, although the number and magnitude of blooms varied. Generally, blooms seem to be occurring more frequently at present than in previous years. Most districts have implemented some form of monitoring program but have not conducted comprehensive studies on factors associated with algal blooms. Because of the lack of 
a cohesive algal bloom factor study, interviewees maintained their own ideas on the occurrence of algal blooms (Table 3).

\begin{tabular}{|c|c|c|}
\hline District & HAB Occurrence & HAB Impact \\
\hline Louisville & $\begin{array}{l}\text { Blooms occur at multiple Corps projects } \\
\text { every summer, late in the season. Blue- } \\
\text { green algae blooms have become a larger } \\
\text { issue in the Louisville District in the past } \\
\text { three years, most often in Indiana lakes, but } \\
\text { also in Ohio and Kentucky bodies of water. } \\
\text { Associated factors are thought to include } \\
\text { eutrophication, oxygen depletion, high } \\
\text { temperatures, and drought conditions. }\end{array}$ & $\begin{array}{l}\text { Multiple projects have reported fish kills. } \\
\text { Anecdotal reports of dogs that died after } \\
\text { jumping into/drinking water high in algal } \\
\text { toxins. Blooms have necessitated an } \\
\text { increase in filtration and application of } \\
\text { carbon to remove taste and toxins in the } \\
\text { water supply. Beaches have been closed } \\
\text { down due to blooms, and some people } \\
\text { have reported skin rashes. }\end{array}$ \\
\hline Norfolk & $\begin{array}{l}\text { Large bloom occurred at the Craney Island } \\
\text { Dredged Material Management Area in the } \\
\text { summer of } 2005 .\end{array}$ & $\begin{array}{l}\text { Algal toxin effects are negligible, as the } \\
\text { toxins dissipate in the wide mixing area of } \\
\text { Norfolk Harbor and recreational activities } \\
\text { do not take place in the region. }\end{array}$ \\
\hline Buffalo & $\begin{array}{l}\text { The Buffalo District manages and maintains } \\
\text { many harbors along the south shore of Lake } \\
\text { Erie, which currently faces multiple problems } \\
\text { and concerns with algal blooms. Blooms } \\
\text { have occurred on Lake Erie every summer, } \\
\text { with a peak of 2-3 weeks, for at least the past } \\
5 \text { years. }\end{array}$ & $\begin{array}{l}\text { No documented human health impacts } \\
\text { have resulted thus far. Beaches have been } \\
\text { closed as a precautionary measure. }\end{array}$ \\
\hline Portland & $\begin{array}{l}\text { Most of the Portland District projects have } \\
\text { experienced algal blooms at one time or } \\
\text { another. Blooms begin in June and last } \\
\text { through the summer. In } 2005 \text {, large blooms } \\
\text { occurred at three of the } 17 \text { district projects; } \\
\text { typically up to two-thirds of the district's } \\
\text { projects experience a large bloom in a given } \\
\text { year. }\end{array}$ & $\begin{array}{l}\text { Despite bloom prevalence, health and } \\
\text { property impacts were not specified. }\end{array}$ \\
\hline Jacksonville & $\begin{array}{l}\text { Blooms occurred at several of the district's } \\
\text { biggest projects in } 2005 \text {. Blooms seem to be } \\
\text { associated with heavy rainfall periods. }\end{array}$ & $\begin{array}{l}\text { Anecdotal reports of dead manatees. Many } \\
\text { human health concerns, especially relating } \\
\text { to potable water. Concerns will likely impact } \\
\text { the design of a costly project where a } \\
\text { downstream water quality treatment } \\
\text { installation could increase costs. }\end{array}$ \\
\hline Tulsa & $\begin{array}{l}\text { Blooms occurred at six of the district's } \\
36 \text { projects in } 2005 \text {. Marion Reservoir in } \\
\text { Kansas blooms annually. }\end{array}$ & $\begin{array}{l}\text { A dog is thought to have gotten sick from } \\
\text { Microcystin at Marion Reservoir, Kansas. A } \\
\text { golden algae bloom at Lake Texoma in } \\
\text { January } 2004 \text { killed } 25-30,000 \text { fish. Golden } \\
\text { algae threaten the striped bass fishery on } \\
\text { the lake, which is a } \$ 40 \text { million/year } \\
\text { economic asset. }\end{array}$ \\
\hline
\end{tabular}

In the Louisville District, blooms occur late in the season in association with eutrophication, oxygen depletion, high temperatures, and drought conditions. In the Buffalo District, algal blooms typically occur on Lake Erie once per summer in August, with a peak bloom lasting about 2-3 weeks and 
being focused on the south shore of the lake. In both of these districts, blooms came earlier than usual in 2005 and seemed to be more pronounced.

Although the Norfolk District had only one project affected by HABs in 2005 - a large bloom which occurred at the Craney Island Dredged Material Management Area - the problem is much more widespread in other districts. Most projects in the Portland District have experienced blooms, and some have blooms on a regular basis. For example, the Hills Creek Reservoir has experienced a blue-green algal bloom early every summer since it was built approximately 40 years ago. Blooms occur most frequently at Hills Creek Reservoir, Lookout Point Reservoir, Dexter Reservoir, and Willow Creek Reservoir. All 17 projects probably had blooms of varying severity during the summer of 2005. Three reservoirs had warning signs posted, and in different years the number of postings can vary from a few to two-thirds of projects.

Many projects in the Jacksonville District also had blooms in 2005. It seemed to the interviewee as though blooms happened more often in 2005 than in previous years, but there is not a reliable historical record. Blooms also seem to be associated with heavy rainfall periods, but rainfall may simply be associated with other summertime variables.

In the Tulsa District, the Marion Reservoir in Kansas experiences blooms annually. The bloom was not as strong in 2005 as in 2004, but it still occurred. Of the 36 projects in the district, blooms have been seen at six of them including the Marion Reservoir, Lake Texoma (golden algae rather than blue-green algae), the Wister Reservoir, Tenkiller Lake, Skiatook Lake, and the Fort Gibson Reservoir. Blue-green algae blooms have also been seen at non-Corps reservoirs, including Cheney Lake (a water supply reservoir for Wichita, KS) and Lake Thunderbird (a water supply reservoir for Norman, OK).

HAB impacts on USACE operations. The interviewees, with the exception of the Norfolk District interviewee, reported that their district has been negatively impacted by HABs in a significant manner. Interviewees reported ecological, human health, and property/construction impacts.

The interviews demonstrated that if harmful algal blooms are adversely affecting ecosystems, knowledge of the impacts is quite limited. Fish kills have been reported at a few Louisville District projects, and there are anecdotal reports of algal toxins killing manatees in Florida and making dogs sick in Kansas and Minnesota. However, these are the only harmful effects of blue-green algae cited by the interviewees. A golden algae bloom at the Tulsa District's Lake Texoma in January 2004 killed 25,000-30,000 fish at a striped bass fishery. Texoma is blue-green dominated, but the impacts there have been due to golden algae.

Although human concern over algal blooms is often quite high, human health impacts associated with blooms have been mild. The only health impacts reported were a few cases of skin rashes in the Louisville District, leading to selected beach closings and charcoal filtration of parts of the water supply. Precautions have also been taken elsewhere, including beach closings in the Buffalo District and health advisories concerning lakes in the Portland District and the St. John's River in the Jacksonville District. None of these districts have reported human health impacts from algal blooms. In the Tulsa District, beach closings and water supply have been an issue at Marion Reservoir, but 
human health has not been affected. Although golden algae killed thousands of fish at Lake Texoma, they do not seem to be harmful to humans.

Few property or construction impacts were named in the interviews. A 9,000-acre storage reservoir is being built on the St. John's River, only a few miles upstream of a drinking water intake. Local members of the public are very concerned about water quality, and possible algae impacts will likely have an impact on the design of this project. The interviewee could only speculate, but the reservoir is a \$300-million project, which suggests any negative impact could have large financial consequences.

HAB management actions at districts. Management actions taken to address algal blooms have generally been very limited (Table 4). The reasons given for this were:

- $\quad$ The district may not have anyone dedicated to the problem of algal blooms.

- Corps operations may be undertaken with a focus on flood control, water supply, or other purpose, which precludes management actions to reduce the extent of algal blooms.

- No response may be taken if, as in the case of the Norfolk District, a bloom is seen as a onetime event.

- Nothing can be done in the short term.

The Louisville District believes that effective solutions for algal blooms lie in the long term, where management activities can be taken to reduce the occurrence of algal blooms by trying to control factors that promote algal growth. This includes upper watershed management practices that lead to reduced nutrient influx to downstream lakes and reservoirs.

The Tulsa District is looking into management options such as using water flow to alleviate bloom effects. The District is currently conducting a feasibility study with the city of Tulsa (using nonCorps reservoirs) that will examine mixing water, decreasing the intensity of stratification, or using bottom-water releases from dams to minimize sediment phosphorous release as ways to address the problem of algal blooms. The District is also conducting a study of the Verdigris River in the Oologah Lake watershed, collecting data and conducting modeling to find management options that would maintain or improve water quality without adversely impacting phytoplankton, fish, recreation, and water supply to the city of Tulsa.

Most often, short-term management actions are taken to keep people away from algal blooms once they occur. The Louisville, Buffalo, and Tulsa Districts closed beaches, for example. In the Tulsa District, the bloom at the Marion Reservoir caused the towns of Hillsboro and Marion, Kansas, to halt water supply from the reservoir for a week. Warning signs were posted, and water trucks were brought into city squares to distribute water.

The Portland District also posted warning signs at water bodies with high levels of algae. In 2005, warning signs were posted at three reservoirs. The posts describe what an algal bloom is, that cells can potentially produce toxins, and that visitors and their pets should stay away from it. The signs also urge common sense when boating or undertaking other activities on the water. Because blooms recur from year to year, permanent postings have been considered. 


\begin{tabular}{|c|c|c|}
\hline District & HAB Management Action & HAB Public Concern \\
\hline Louisville & $\begin{array}{l}\text { Some beaches closed and some drinking } \\
\text { water filtered. Corps projects are undertaken } \\
\text { with a focus on flood control rather than HAB } \\
\text { management. HAB solution is seen in long- } \\
\text { term upper watershed management to change } \\
\text { root of problem. }\end{array}$ & $\begin{array}{l}\text { The interviewee estimated that local } \\
\text { government agencies spend } 10 \text { times } \\
\text { more time on HABs now than they did } \\
\text { five years ago. }\end{array}$ \\
\hline Norfolk & $\begin{array}{l}\text { No response taken because state standards } \\
\text { are averages over time, whereas a bloom is } \\
\text { seen as one-time event. }\end{array}$ & $\begin{array}{l}\text { Some members of the public have } \\
\text { speculated that the Craney Island HAB } \\
\text { could have been caused by Corps } \\
\text { dredging operations. }\end{array}$ \\
\hline Buffalo & $\begin{array}{l}\text { No state action was taken aside from beach } \\
\text { closings. }\end{array}$ & $\begin{array}{l}\text { Some members of the public, and a } \\
\text { Congressman, believe that dredging and } \\
\text { open water placement operations may } \\
\text { aggravate HABs on Lake Erie. }\end{array}$ \\
\hline Portland & $\begin{array}{l}\text { Warnings are posted by projects with algae } \\
\text { levels above certain threshold. Permanent } \\
\text { postings have been considered. }\end{array}$ & $\begin{array}{l}\text { The public sees posted warning signs } \\
\text { and sometimes calls. The interviewee } \\
\text { estimates that dealing with algal blooms } \\
\text { currently occupies } 20 \% \text { of his time, } \\
\text { whereas they took } 5 \% \text { of his time three } \\
\text { years ago. }\end{array}$ \\
\hline Jacksonville & No management actions specified. & $\begin{array}{l}\text { HABs have received large amount of } \\
\text { attention due to newspaper articles } \\
\text { attempting to link blooms to USACE } \\
\text { operations. }\end{array}$ \\
\hline Tulsa & $\begin{array}{l}\text { During the Marion Reservoir bloom, swim } \\
\text { beaches were closed, warning signs were } \\
\text { posted, and drinking water was trucked in for a } \\
\text { week. USACE is conducting a feasibility study } \\
\text { with the city of Tulsa to investigate possible } \\
\text { management techniques. }\end{array}$ & $\begin{array}{l}\text { The interviewee estimated that calls from } \\
\text { the public have increased recently, but } \\
\text { not significantly. USACE answered two } \\
\text { Congressional inquiries about blooms on } \\
\text { the Marion Reservoir in } 2004 \text {. }\end{array}$ \\
\hline
\end{tabular}

Stakeholder/public pressure and concerns from personal interviews. Recently, public concern about algal blooms has been increasing: citizens are often concerned about their local water quality and multiple congressional inquiries have been made in response to algal blooms and USACE operations.

In all six districts, members of the public often call to ask questions about algal blooms. The interviewee in the Louisville District estimated that local government agencies are currently spending approximately 10 times more of their time addressing the issue of harmful algal blooms than they were five years ago. For instance, Indiana has a blue-green algal toxin task force; Kentucky is developing one as well. In the Portland District, the public often calls after seeing posted warning signs. One interviewee estimated that algal blooms have risen from 5 percent of his effort in the last three years to 20 percent now and the other six people in his group have probably doubled their time (from 5 to 10 percent). 
Inter-agency interactions responding to algal blooms. Responding to algal blooms is often a complicated, multi-agency process. Interviewees explained that the process is characterized by uncertainty about agency roles and health advisory criteria. In the Buffalo District, agencies involved in Lake Erie include the Ohio Department of Health, the Ohio EPA, the Ohio Department of Natural Resources, and at times also the USEPA. In the Jacksonville District, agencies involved with algal blooms include the Florida Department of Environmental Protection, the South Florida Water Management District, and, to a lesser extent, the USEPA. In both of these cases, the responsibilities for the local groups are not clearly defined.

Many different agencies are involved with the Tulsa District. In Oklahoma, the USACE has been working with the Department of Environmental Quality (which makes advisory determinations). USACE also works with the Oklahoma Water Resources Board (enforces standards and monitors lakes), the Oklahoma Conservation Commission (monitors streams), and the Red River Valley Association (involved with Lake Texoma). Other agencies include the Kansas Department of Health and Environment (posts health warnings), the Kansas Water Office, and the Texas Commission on Environmental Quality.

The situation in the Portland District, although also not well-defined, has settled into a routine wherein USACE may become involved in either of two ways. In USACE projects surrounded by Forest Service land, a Forest Service worker may notice an algal bloom and take samples to analyze algae cell counts. If the resulting cell count is high (above, say, 100,000 cells/mL), the Forest Service will notify USACE and the Oregon Department of Health, and the state will then make a decision (in conjunction with the Forest Service and USACE) to post warning signs at the project and collect follow-up samples. In this case, USACE coordinates with the Forest Service. In projects that do not involve the Forest Service, USACE resource personnel may observe reservoirs and take samples, and after consulting the state, this may also lead to posting.

The Oregon Department of Health decides whether the posting of a reservoir should occur. Although it has a decision-making protocol, the decision-making plan is an ongoing development. Initial guidelines were taken from the American Waterworks Association publication Cyanobacterial BlueGreen Algae Toxins: A Resource Guide, which contains a flow chart with protocol for assessing algae blooms. The guidelines are still in development, however, and there is currently no state standard.

STUDY LIMITATIONS: Any conclusions drawn from the limited literature review and interviews conducted in this study suffer from a number of drawbacks. The literature review examined only a small portion of the research available on algal blooms and conducted a targeted search to fill any gaps in the initial review. Personnel interviews were limited by the small number of people interviewed. Interviews were based on what interviewees were able to correctly remember regarding current and historical facts about their districts. Additional studies should be taken to prepare Corps personnel to be more efficient in preventing and mitigating HABs, as well as to communicate with the public and other stakeholders.

CONCLUSIONS: The purpose of this note was to examine the current literature for algal bloom management techniques and to identify the impacts algal blooms are having on USACE activities by means of personnel surveys. 
The literature review indicates that USACE operations are able to influence the development of algal blooms through a variety of physical and chemical means. Physical factors are readily adjustable and capable of influencing numerous other factors. Chemical factors are more difficult to control but are beneficial in controlling algal bloom occurrences in the long term.

The interviews indicate that algal blooms present a problem to the USACE and suggest that USACE control of water reservoirs may have a direct impact on the occurrence as well as prevention of HABs. Each contacted district had experienced a bloom. Interviewees agreed that it would be helpful if guidance were available that clarified USACE's responsibility in response to an algal bloom (when and how to communicate risk to the public, when to issue health warnings or take other management actions, and which agency is responsible for issuing health warnings). Although difficult to quantify, HABs are costing the USACE money and resources, and the occurrence of blooms appears to have an upward trend.

POINTS OF CONTACT: For additional information, contact Dr. Jeffrey A. Steevens (601-6344199, Jeffery.A.Steevens@usace.army.mil) or the Program Manager of the Aquatic Nuisance Species Research Program (ANSRP), Glenn Rhett (601-634-3717, Glenn.G.Rhett@usace.army.mil). This technical report should be cited as follows:

Linkov, I., F. K. Satterstrom, D. Loney, and J. A. Steevens. 2008. The impact of harmful algal blooms on USACE operations. ANSRP Technical Notes Collection (ERDC/TN ANSRP-09-1). Vicksburg, MS: U.S. Army Engineer Research and Development Center. http://el.erdc.usace.army.mil/ansrp/ansrp.html.

\section{REFERENCES:}

Amé, M., M. del Pilar Diaz, and D. Wunderlin. 2003. Occurrence of toxic cyanobacterial blooms in San Roque Reservoir (Cordoba, Argentina): A field and chemometric study. Environmental Toxicology 18: 192-201.

Barnese-Walz, L. 2005. Telephone interview. August 19, 2005.

Becker, A., A. Herschel, and C. Wilhelm. 2006. Biological effects of incomplete destratification of hypertrophic freshwater reservoir. Hydrobiologia 559(1): 85-100.

Britton, J. 2005. Telephone interview. September 30, 2005.

Carmichael, W., ed. 2005. A world overview: One hundred twenty seven years of research on toxic cyanobacteria: Where do we go from here? In International Symposium on Cyanobacterial Harmful Algal Blooms, September 6-10, 2005. NC, USA: Research Triangle Park.

Chorus, I., and J. Bartram. 1999. Toxic cyanobacteria in water: A guide to their public health consequences. Retrieved October 24, 2005, from http://www.who.int/docstore/water_sanitation_health/toxicyanobact/begin.htm.

Clyde, T. 2005. Telephone interview. October 18, 2005.

Cole, R., P. Scodari, and M. Franklin. 2005. Impacts and management costs caused by freshwater aquatic nuisance species at civil works projects operated by the United States Army Corps of Engineers. Unpublished manuscript.

Connolly, N. M., M. R. Crossland, and R. G. Pearson. 2004. Effect of low dissolved oxygen on survival, emergence, and drift of tropical stream macroinvertebrates. N. Am. Benthol. Soc. 23(2): 251-270.

Donnelly, T. H., M. R. Grace, and B. T. Hart. 1997. Algal blooms in the Darling-Barwon River, Australia. Water, Air, and Soil Pollution 99: 487-496.

Glibert, P., J. Harrison, C. Heil, and S. Seitzinger. 2006. Escalating worldwide use of urea - a global change contributing to coastal eutrophication. Biogeochemistry 77: 441-463. 
Huisman, J., H. C. P. Matthijs, and P. M. Visser. 2005. Harmful cyanobacteria (2005th ed., 41-63, 109-142).

Jeppesen, E., M. Meerhoff, B. A. Jacobsen, R. S. Hansen, M. Sondergaard, and J. P. Jensen. 2007. Restoration of shallow lakes by nutrient control and biomanipulation - the successful strategy varies with lake size and climate. Hydrobiologia 581(1): 269-285.

Ji, R., and P. Franks. 2007. Vertical migration of dinoflagellates: Model analysis of strategies, growth, and vertical distribution patterns. Marine Ecology Progress Series 344(1): 49-61.

Kim, H., S. Hwang, J. Shin, K. An, and C. G. Yoon. 2007. Effects of limiting nutrients and N:P ratios on the phytoplankton growth in a shallow hypertrophic reservoir. Hydrobiologia 581: 255-267.

Kunz, T., and S. Diehl. 2003. Phytoplankton, light and nutrients along a gradient of mixing depth: A field test of producer-resource theory. Freshwater Biology 48(6): 1050-1063.

Linkov, I., A. Fristachi, F. K. Satterstrom, A. Shifrin, J. Steevens, and G. A. Clyde, Jr. 2007. Identifying data gaps and the need for a management framework. In Harmful cyanobacterial blooms, 207-242. The Netherlands: Springer.

McCarthy, M. J., P. J. Lavrentyev, L. Yang, L. Zhang, Y. Chen, B. Qin, and W. Gardner. 2007. Nitrogen dynamics and microbial food web structure during a summer cyanobacterial bloom in a subtropical, shallow, well-mixed, eutrophic lake (Lake Taihu, China). Hydrobiologia 581: 195-207.

Mhlanga, L., J. Day, M. Chimbari, N. Siziba, and G. Cronberg. 2006. Observations on limnological conditions associated with a fish kill of oreochromis niloticus in Lake Chivero following collapse of an algal bloom. African Journal of Ecology 44(2): 199-208.

Nakano, K., T. J. Lee, and M. Matsumura. 2001. In situ algal bloom control by the integration of ultrasonic radiation and jet circulation to flushing. Environmental Science \& Technology 35(24): 4941-4946.

National Oceanic and Atmospheric Administration (NOAA). 2008. Summary: The harmful algal bloom and hypoxia research and control act. Retrieved June 15, 2008, from www.cop.noaa.gov/stressors/extremeevents/hab/habhrca/.

Nelson, T. A., A. V. Nelson, and M. Tjoelker. 2003. Seasonal and spatial patterns of “Green tides” (ulvoid algal blooms) and related water quality parameters in the coastal waters of Washington State, USA. Botanica Marina. 46(3): 263275.

Nõges, P., M. Kagu, and T. Noges. 2007. Role of climate and agricultural practice in determining matter discharge into large, shallow lake Vortsjarv, Estonia. Hydrobiologia 581(1): 125-134.

Paerl, H. 1996. A comparison of cyanobacterial bloom dynamics in freshwater, estuarine and marine environments. Phycologia 35(Supplement): 25-35.

Paerl, H. 2008. Nutrient and other environmental controls of harmful cyanobacterial blooms along the freshwater-marine continuum. Advances in Experimental Medicine and Biology 619(1): 217-237.

Pertola, S., H. Kuosa, and R. Olsonsen. 2005. Is the invasion of prorocentrum minimum (dinophyceae) related to the nitrogen enrichment of the Baltic Sea? Harmful Algae 4(3): 481-492.

Pickard, S. 2005. Telephone interview. August 30, 2005.

Poovey, A., and M. Netherland. 2006. Identification and initial screening of new compounds to control harmful algal blooms. ERDC/TN ANSRP-06-2. Vicksburg, MS: U.S. Army Corps of Engineers.

Repka, S., M. Koivula, V. Harjunpa, L. Rouhiainen, and K. Sivonen. 2004. Effects of phosphate and light on growth of and bioactive peptide production by the cyanobacterium anabaena strain 90 and its anabaenopeptilide mutant. Applied and Environmental Microbiology 70(8): 4551-4560.

Rhudy, K. B., V. K. Sharma, R. L. Lehman, and D. A. Mackee. 1999. Seasonal variability of the Texas 'brown tide' (aureoumbra lagunensis) in relation to environmental parameters. Estuarine, Coastal and Shelf Science 48(5): 565574.

Robarts, R., M. Waiser, M. Arts, and M. Evans. 2005. Seasonal and diel changes of dissolved oxygen in a hypertrophic prairie lake. Lakes \& Reservoirs: Research and Management 10(3): 167-177. 
Rolland, A., D. Bird, and A. Giani. 2005. Tracing river influences on phytoplankton dynamics in two Louisiana estuaries. Journal of Plankton Research 27(7): 683-694.

Seitzinger, S. 1991. The effect of $\mathrm{pH}$ on the release of phosphorus from Potomac estuary sediments: Implications for blue-green algal blooms. Estuarine, Coastal and Shelf Science 33: 409-418.

Shafer, M. 2005. Telephone interview. October 5, 2005.

Shapiro, J. 1990. Current beliefs regarding dominance by blue-greens: The case for the importance of $\mathrm{CO} 2$ and $\mathrm{pH}$. Verhandlungen Der Internationalen Vereinigung Fur Theoretische Und Angewandte Limnologie 24: 28-54.

Sthapit, E., C. Ochs, and P. Zimba. 2008. Spatial and temporal variation in phytoplankton community structure in a southeastern U.S. reservoir determined by HPLC and light microscopy. Hydrobiologia 600(1): 215-228.

Van Dolah, F. 2000. Marine algal toxins: Origins, health effects, and their increased occurrence. Environmental Health Perspective 108(S1).

Verspagen, J., J. Passarge, K. Johnk, P. Visser, L. Peperzak, and P. Boers. 2006. Water management strategies against toxic microcystis blooms in the Dutch delta. Ecological Applications 16(1): 313-327.

Vézie, C., L. Brient, K. Sivonen, G. Bertru, J. Lefeuvre, and M. Salkinoja-Salonen. 1998. Variation of microcystin content of cyanobacterial blooms and isolate strain in Lake Grand-Lieu (France). Microbial Ecology 35(2): 126-135.

Vézie, C., J. Rapala, J. Vaitomaa, J. Seitsonen, and K. Sivonen. 2002. Effect of nitrogen and phosphorous on growth of toxic and nontoxic microcystis strains and on intracellular microcystin concentrations. Microbial Ecology 43(4): 443-454.

Watson, C., and R. Yanong. 2006. Use of copper in freshwater aquaculture and farm ponds. Retrieved June 16, 2008, from http://edis.ifas.ufl.edu.

Wissel, B., A. Gace, and B. Fry. 2005. Tracing river influences on phytoplankton dynamics in two Louisiana estuaries. Ecology 86(10): 2751-2762.

Woods Hole Oceanographic Institute. 2008. Red tide and harmful algal blooms. Retrieved June 14, 2008, from http://www.whoi.edu/redtide/.

Zhaosheng, C., X. Jin, N. Iwami, and Y. Inamori. 2007. The effect of temperature on growth characteristics and competitions of microcystis aeruginosa and oscillatoria mougeotii in a shallow, eutrophic lake simulator system. Hydrobiologia 581(1): 217-223. 


\section{APPENDIX}

HAB MONITORING DATA: In an effort to gain information that will help districts better manage projects, districts are also collecting water quality data at many projects. Perhaps, after analysis, this data will help to further elucidate the factors associated with high probability of algal blooms.

\begin{tabular}{|c|c|}
\hline District & HAB Monitoring \\
\hline Louisville & $\begin{array}{l}\text { The Louisville District collects data from each of their reservoir projects, from the inflows } \\
\text { and from the tail waters. At Harsha Lake the District conducted a modeling study, } \\
\text { collecting data on a weekly basis through the summer of } 2005 \text {. Sampling included five } \\
\text { locations within the lake every four weeks at different depths. Measurements included } \\
\text { metals, nutrients, phytoplankton, chlorophyll, and physical parameters. However, the } \\
\text { budget only contains enough money to monitor other locations once a year (in August or } \\
\text { September). The Corps collects water for analysis from different depths at tail waters, dam } \\
\text { sites, and major tributaries. Special circumstances may warrant a closer look at other } \\
\text { places. Other agencies, such as the Division of Water, Fish \& Wildlife, and USGS, also } \\
\text { collect data in Kentucky, as well as many Indiana agencies. }\end{array}$ \\
\hline Norfolk & $\begin{array}{l}\text { The Norfolk District has recently measured chlorophyll A levels at Craney Island. USACE } \\
\text { noticed these levels increasing over the summer of } 2005 \text {. Levels started fairly low (i.e. } \\
\text { levels the previous winter were around } 1-2 \text { ug/L, but levels in the spring and summer were } \\
15-20 \text { ug/L). USACE does not have past summer background measurements and has not } \\
\text { done testing until the last few years. }\end{array}$ \\
\hline Buffalo & The Buffalo District does not collect data related to algal blooms. \\
\hline Portland & $\begin{array}{l}\text { For the past ten years, the Portland District has taken comprehensive measurements at } \\
\text { three projects: the Willow Creek Reservoir (which often experiences algal blooms), Lost } \\
\text { Creek Lake, and Applegate Dam. Sample analysis consists of organism ID, cell counts, } \\
\text { cell density, and biovolume, as well as environmental factors (including temperature, pH, } \\
\text { turbidity, dissolved oxygen, dissolved solids, etc.). Samples are generally } 500 \mathrm{~mL} \text { to } 1 \mathrm{~L} \text {, } \\
\text { taken from the top layer of water. Due to budget constraints, samples are not taken } \\
\text { regularly at other projects and often include analysis for fewer factors. The interviewee } \\
\text { estimated that monitoring all projects on a weekly basis would take over } \$ 100,000 \text { per } \\
\text { year, which is much larger than the District's entire water quality budget. }\end{array}$ \\
\hline Jacksonville & $\begin{array}{l}\text { Rather than USACE, the Florida DEP and South Florida Water Management District often } \\
\text { sample for algal blooms. The Jacksonville District has, however, collected data about } \\
\text { cyanobacteria at sites connected with the Aquifer Storage \& Recovery Project. These data } \\
\text { are taken from four sites (Lake Okeechobee, Kissimmee River, Hillsboro Canal, } \\
\text { Caloosahatchee River), quarterly for one year. Sampling is expensive. }\end{array}$ \\
\hline Tulsa & $\begin{array}{l}\text { In } 2005 \text {, the Tulsa District took measurements at the Marion and Fort Gibson reservoirs. } \\
\text { Microcystin levels ranged from } 2.9 \text { to } 9.6 \mathrm{ppb} \text { at Marion (June } 8 \text { th to July } 13 \text { th, samples } \\
\text { taken every two weeks, possibly } 60 \text { or } 70 \text { samples); } 2.8 \text { to } 3.6 \mathrm{ppb} \text { at Fort Gibson (July } 6 \text { th, } \\
\text { possibly } 40 \text { samples). Samples were also taken at Tenkiller Reservoir in } 2005 \text {, and } \\
\text { Skiatook Lake samples were taken on a day at peak of cylindrospermopsin bloom near a } \\
\text { swim beach. All told, approximately } 360 \text { samples were taken during the year. Data include } \\
\text { nutrient levels, total phosphorous, nitrate/nitrite, ammonia, organic carbon, chloride, and } \\
\text { total calcium in some lakes, as well as vertical profiles of turbidity, oxygen, pH, } \\
\text { conductivity, temperature, chlorophyll, and some light data. Most samples are surface } \\
\text { samples; others are a half meter below surface or a meter above the bottom, taken in 1-L } \\
\text { amber bottles, split between microcystin and cylindrospermopsin analysis. Historically, the } \\
\text { District has had chlorophyll data, but now Dr. Bob Lynch at OU is doing phytoplankton } \\
\text { analysis for them. }\end{array}$ \\
\hline
\end{tabular}

